\title{
Growth Performance, Carcass Characteristics and Serum Biochemistry of Broiler Chicken Fed Graded Levels of Sun-Dried Irish Potato Peel Meal
}

\author{
Raphael James Wafar ${ }^{1 *}$, Perpetual Ebere Ojinnaka ${ }^{1}$, Luka Isa Tarimbuka ${ }^{2}$, \\ Deacon Samuel Iliya ${ }^{2}$, Isa Ibrahim Shehu ${ }^{3}$
}

\begin{abstract}
${ }^{1}$ Department of Animal Production and Health, Federal University, Wukari P.M.B 1020, Wukari, Taraba State. Nigeria.
${ }^{2}$ Department of Animal Health and Production Technology, Adamawa State College of Agriculture, Ganye. P.M.B 2088 Ganye, Adamawa State. Nigeria. ${ }^{3}$ Department of Animal science, School of Vocational Education, Federal College of Education (Technical), PMB 1013 Potiskum, Yobe State. A R T ICLE IN F O

Research Article

Received 11 November 2016

Accepted 11 May 2017

\section{Keywords:}

Sun-dried Irish Potatoes

Broiler

Serum biochemistry

*Corresponding Author:

E-mail: wafar@ fuwakari.edu.ng A B S T R A C T

An experiment was conducted to evaluate the effect of substituting different levels of sun-dried Irish potato peel meal (SPPM) for maize in diets of broiler chickens. Five diets in which SPPM was replaced with 0 (OSPPM), 25 (25SPPM), 50 (50SPPM), 75 (75SPPM) and 100\% (100SPPM) of maize in starter and finisher diets for a 8 week period using broiler chickens were examined. A total of 300 two weeks old broilers chicks Anak 2000 were randomly allotted to five experimental diets with six pen per treatment and 10 birds chicks per pen. Body weight and feed intake of broilers, and feed conversion ratio were determined at the beginning and $56^{\text {th }}$ day of the experiment respectively. On day 56, four broilers from each pen were selected and slaughtered to determine some carcass characteristics and serum biochemistry. The result of growth performance showed that 100SPPM decreased daily weight gain of chickens when compared to other SPPM levels $(\mathrm{P}<0.05)$. Dietary SPPM did not affect feed intake and feed conversion ratio $(\mathrm{P}<0.05)$. Carcass weight, dressing percentage, and studied serum biochemistry values of chickens in OSPPM were higher than that of other treatments $(\mathrm{P}<0.05)$.It can be concluded that SIPM can replace maize up to $75 \%$ in broiler chicken diets without any adverse effect on growth performance, carcass characteristics and serum biochemistry performance Carcass yield, Blood parameters.
\end{abstract}

DOI: https://doi.org/10.24925/turjaf.v5i5.525-529.1070

\section{Introduction}

Broiler production is one the livestock industries that offers the highest turnover rate and quicker returns on investment either in small, medium or large scale production (Afolayan et al., 2014). The potentials of the industry is affected by the high cost of feed especially energy and protein sources. The prices of energy source for livestock feed have been on increase in Nigeria (Midau et al., 2011). The major source of energy is maize. However, maize is required by humans and processing industries, thereby causing a tacit competition between human and animals. Price of maize have soared so high in recent times and is no longer economical to be use in poultry feeds formulation (Bot et al., 2013) Continual increase in prices of conventional feedstuff has necessitated the search for alternatives to the expensive energy and protein sources (Ekeyem et al., 2006)

One of such alternatives for replacement of maize in animal diets is the sundried Irish potatoes peel meal (PPM). Irish potatoes peel in Nigeria is always discarded as waste and often allowed to rot and thus pose a disposal problem in the environment. The relative availability and low cost of Irish potatoes peel make it an option in livestock feeding (Wafar and Tarimbuka, 2016).
However, the authors further revealed that the metabolisable energy (ME), crude protein (CP), crude fibre $(\mathrm{CF})$, ether extract and ash contents of PPM were $3118.42 \mathrm{kcal}, 116.1,80.1,20.50$ and $62.10 \mathrm{~g} / \mathrm{kg}$ dry matter. Wafar and Tarimbuka (2016) reported that the PPM was enhanced the performance of rabbits without affecting growth performance and blood parameters. However, information on the effects of PPM based diets on the growth performance; carcass characteristics and serum biochemical of broiler chickens are scanty. The study was therefore aimed at investigating the effect of PPM on the growth performance, carcass characteristics and serum biochemical of broiler chickens.

\section{Materials and Methods}

The study was carried out at Concordia College farm located at Ngurore, Adamawa State, Nigeria. Ngurore lies between latitude $9^{\circ} 16^{\prime} 59^{\prime \prime}$ North and longitude $12^{\circ} 13$ ' $59^{\prime \prime}$ East. Temperature is high in February, March and April because of high radiation, which is evenly distributed throughout the year (Adebayo and Tukur, 1999). The Irish potatoes peel were sourced within Jimeta metropolis, sun 
dried on a clean cemented floor for 8 days. The dried samples were ground using hammer mill, packed in a sack and stored at room temperature (Wafar and Tarimbuka, 2016)

In this study, a total of 300 day old Anak 2000 broiler was used. The birds were randomly allotted to five dietary treatments of six replicates, with ten birds each in a completely randomized design. The experimental diets consisted of a control group and four levels of SPPM replacing $25,50,75$ or $100 \%$ of maize, respectively. Hence, treatments were: control (OSPPM), 25 SPPM, 50SPPM, 75SPPM and 100SPPM. All diets were offered ad libitum. Clean and fresh water was available at all times. The experiment lasted for 8 weeks. The composition and calculated nutrient and energy levels of experimental diets (starter from 1 to 35 days of age; finisher from 35 to 56 days of age) are given in Table 1.

Table 1 ingredient composition experimental diets (starter and finisher)

\begin{tabular}{|c|c|c|c|c|c|}
\hline \multirow{2}{*}{ Ingredient $(\mathrm{g} / \mathrm{kg})$} & \multicolumn{5}{|c|}{ Starter (from 1 to 35 day of age) } \\
\hline & OPPM & $25 \mathrm{PPM}$ & $50 \mathrm{PPM}$ & $75 \mathrm{PPM}$ & 100PPM \\
\hline SIPM & 0.00 & 12.00 & 24.00 & 36.00 & 48.00 \\
\hline Maize & 48.00 & 36.00 & 24.00 & 12.00 & 0.00 \\
\hline Soybean meal & 28.70 & 28.70 & 28.70 & 28.70 & 28.70 \\
\hline Wheat offal & 16.00 & 16.00 & 16.00 & 16.00 & 16.00 \\
\hline Fishmeal & 3.00 & 3.00 & 3.00 & 3.00 & 3.00 \\
\hline Bone meal & 2.50 & 2.50 & 2.50 & 2.50 & 2.50 \\
\hline Premix $^{*}$ & 0.25 & 0.25 & 0.25 & 0.25 & 0.25 \\
\hline Limestone & 1.00 & 1.00 & 1.00 & 1.00 & 1.00 \\
\hline Lysine & 0.10 & 0.10 & 0.10 & 0.10 & 0.10 \\
\hline Methionine & 0.20 & 0.20 & 0.20 & 0.20 & 0.20 \\
\hline Salt & 0.25 & 0.25 & 0.25 & 0.25 & 0.25 \\
\hline \multicolumn{6}{|c|}{ Analysed nutrition composition } \\
\hline Dry matter & 89.21 & 89.00 & 88.12 & 89.41 & 86.21 \\
\hline Crude protein & 21.21 & 23.02 & 23.42 & 23.07 & 23.09 \\
\hline Crude fibre & 4.12 & 4.25 & 6.21 & 6.02 & 6.09 \\
\hline Ether extracts & 6.2 & 5.40 & 4.89 & 5.05 & 5.02 \\
\hline Ash & 4.42 & 5.13 & 5.26 & 5.29 & 5.32 \\
\hline NFE & 64.05 & 62.20 & 65.11 & 60.57 & 60.48 \\
\hline \multicolumn{6}{|c|}{ Calculated nutrition composition } \\
\hline ME Kcal/kg & 2809.01 & 2804.00 & 2815.08 & 2811.00 & 2810.22 \\
\hline $\mathrm{Ca}$ & 1.08 & 1.09 & 1.11 & 1.10 & 1.12 \\
\hline Available P & 0.50 & 0.62 & 0.61 & 0.60 & 0.62 \\
\hline Ingredient $(\mathrm{g} / \mathrm{kg})$ & \multicolumn{5}{|c|}{ Finisher (from 35 to 56 day of age) } \\
\hline SIPM & 0.00 & 14.00 & 28.00 & 42.00 & 56.00 \\
\hline Maize & 56.00 & 42.00 & 28.00 & 14.00 & 0.00 \\
\hline Soybean meal & 25.70 & 25.70 & 25.70 & 25.70 & 25.70 \\
\hline Wheat offal & 11.00 & 11.00 & 11.00 & 11.00 & 11.00 \\
\hline Fishmeal & 3.00 & 3.00 & 3.00 & 3.00 & 3.00 \\
\hline Bone meal & 2.50 & 2.50 & 2.50 & 2.50 & 2.50 \\
\hline Premix ${ }^{*}$ & 0.25 & 0.25 & 0.25 & 0.25 & 0.25 \\
\hline Limestone & 1.00 & 1.00 & 1.00 & 1.00 & 1.00 \\
\hline Lysine & 0.10 & 0.10 & 0.10 & 0.10 & 0.10 \\
\hline Methionine & 0.20 & 0.20 & 0.20 & 0.20 & 0.20 \\
\hline Salt & 0.25 & 0.25 & 0.25 & 0.25 & 0.25 \\
\hline \multicolumn{6}{|c|}{ Analyzed nutrition composition } \\
\hline Dry matter & 86.21 & 90.21 & 89.23 & 88.45 & 90.32 \\
\hline Crude protein & 20.12 & 19.02 & 19.00 & 19.06 & 19.20 \\
\hline Crude fibre & 4.35 & 5.78 & 7.05 & 8.52 & 9.00 \\
\hline Ether extracts & 3.55 & 3.25 & 3.02 & 3.01 & 3.00 \\
\hline Ash & 4.42 & 5.30 & 5.62 & 5.92 & 6.21 \\
\hline NFE & 67.56 & 66.65 & 65.31 & 63.49 & 62.59 \\
\hline \multicolumn{6}{|c|}{ Calculated nutrition composition } \\
\hline ME Kcal/kg & 3072.0 & 3049.50 & 3040.60 & 3047.40 & 3043.00 \\
\hline $\mathrm{Ca}$ & 1.09 & 1.10 & 1.20 & 1.00 & 1.11 \\
\hline Available P & 0.55 & 0.56 & 0.62 & 0.60 & 0.62 \\
\hline
\end{tabular}


Proximate composition of the experimental diets and SPPM were analyzed by the method of AOAC, (2000). The birds were reared on deep litter in an open-sided wire mesh constructed poultry house to allow for adequate ventilation. The chicks were housed in groups in floor pens with wood-shavings $(122 \mathrm{~cm} \times 125 \mathrm{~cm} \times 120 \mathrm{~cm})$ and the pens were fitted with feeders and waterers. Average ambient temperature was $30^{\circ} \mathrm{C}$ and the relative humidity was maintained within a range of $40-55 \%$. Medications, vaccinations and other routine management practices as described by Abdo et al. (2015) were strictly followed. The birds were offered experimental diets throughout the period of the experiment. Growth performance was assessed by measuring feed intake (FI) and body weight (BW) weekly, and from these data daily weight gain (DWG, g), daily FI (DFI, g) and feed conversion ratio (FCR, g feed:g gain) were calculated. Mortality was recorded as it occurred.

On day 56, four broilers from each replication with body weight within 1 standard deviation of the mean treatment weight (16 birds per treatment) were selected and fasted for $16 \mathrm{~h}$, and then slaughtered to determine carcass yield, some non-carcass parts and internal organs characteristics, and serum biochemistry. Two of these birds were sacrificed by severing their jugular veins with sharp surgical knife. The birds were immersed in hot water $\left(80^{\circ} \mathrm{C}\right)$ for two minutes, de-feathered. The birds were eviscerated and internal contents were neatly removed and weighed followed by the cutting of the carcass into retail parts and weighed as described by Kleczek et al. (2007). Weights of non-carcass parts and internal organs were expressed as a portion of body weight $(\mathrm{g} / 100 \mathrm{~g}$ body weight).

Other two birds per replicate were used for blood collection. Blood was collected using a $2 \mathrm{ml}$ disposable sterile syringe and needle from wing vein into sterile test tubes without anticoagulant for serological study. Parameters (Albumin, Creatinine, Globulin and total protein) were determined using the standard clinical chemistry procedure by Reitman and Frankel, (1957) as cited by Okpanachi et al. (2014).

\section{Statistical Analysis}

For performance data, pen means served as the experimental unit for statistical analysis. For data on relative weights and length of the gut, individual birds were considered as the experimental unit. All data were analysed according to the anova model, using the ONEWAY procedure of Statistix version 10 Software. When the F-test was significant, differences were determined by Duncan's multiple range test using the Duncan option of the same statistical software. Results are presented as means and a pooled standard error of mean (SEM)

\section{Result and Discussion}

The proximate composition of SPPM is shown in Table 2. All the proximate composition determined in the present study was higher than the values of unfermented Irish potatoes peel reported by Akintomide and Antai, (2012). Differences in the nutrient composition could be as a result of environmental factors such soil type, season when the peel was collected and processing methods employed and depth of peeling during processing. The nutrient compositions of the diets are adequate and within the recommended range for broiler starter and finishers as reported by (NRC, 1994; Olomo, 1995; Oluyemi and Robert, 2000).

Table 2 Proximate Composition of sun dried Irish potatoes peel meal SIPM (\%DM)

\begin{tabular}{l|c}
\hline \multicolumn{1}{c|}{ Constituents } & Percentage composition \\
\hline Dry matter & 93.21 \\
Crude protein & 11.61 \\
Crude Fibre & 8.01 \\
Ether extracts & 2.05 \\
Ash & 6.21 \\
Nitrogen Free Extracts & 72.08 \\
ME (kcal/kg) & 3118.42 \\
\hline
\end{tabular}

Metabolizable Energy $=\mathrm{ME}(\mathrm{kcal} / \mathrm{kg})=37 \times \% \mathrm{CP}+81 \times \% \mathrm{EE}+35.5$ $\mathrm{x} \%$ NFE. Calculated according to the formula of Pauzenga, (1985

The performance of broiler chicken is presented in Table 3. The results showed that final weight were statistically similar significantly $(\mathrm{P}<0.05)$ up till $75 \%$ (R4). 100\% SPPM (R5) resulted in significant $(\mathrm{P}<0.05)$ decreased in final weight. Feed intake was not significantly affected $(\mathrm{P}>0.05)$ by diets with the replacement of maize with SPPM but appeared to decrease on the SPPM - based diets. This result agreed with the report by Okapanchi et al. (2015) who reported non- significant $(\mathrm{P}>0.05)$ on feed take of birds fed yam peel. Bird on R3 diet recorded the highest feed intake. The increased in feed intake in R3 diet was probably due to the ratio of $50 \%$ maize and 50\% SPPM effect on the metabolisable energy of the diet, since birds according to (Dafwang and Damang, 1995) are known to eat in order to meet their energy requirement. The decreased in feed intake observed in this study as the SPPM increases, negates the finding of Okapanchi et al. (2015) who reported that high fibre diets increase feed intake in broiler chicken. The feed conversion ratio (FCR) did not show significant difference $(\mathrm{P}<0.05)$ across the dietary treatments. The range observed in this study is within the value $1.00-2.5$ reported by (Amaefule et al., 2005).

Table 4 shows the result of carcass and internal organ characteristics of broiler chickens fed SIPM based diets. The live weight, carcass weight and dress weight and dressing percent were significantly $(\mathrm{P}<0.05)$ affected by replacement levels of SPPM. Prime cut parts (breast, thigh and drumstick) weight differs significantly $(\mathrm{P}<0.05)$ among the dietary treatments except for wing and back, which was not significantly $(\mathrm{P}<0.05)$ affected by replacement. Internal organs such as gizzard, liver and lungs were significantly $(\mathrm{P}<0.05)$ influenced by the level of replacement. Birds fed SIPM -based diets were higher $(\mathrm{P}<0.05)$ on carcass weight. 
Table 3 initial body weights (IBW), daily weight gain (DWG), daily feed intake (DFI) and feed conversion ratio (FCR) of broilers fed graded levels of sun-dried Irish potatoes peel meal incorporated into diets

\begin{tabular}{|c|c|c|c|c|c|c|c|}
\hline Parameter & OPPM & 25PPM & 50PPM & 75PPM & 100PPM & SEM & $\mathbf{P}$ \\
\hline IBW, g per bird & 156.00 & 156.01 & 155.99 & 156.05 & 156.04 & $1.57^{\mathrm{NS}}$ & NS \\
\hline Final weight, g per bird & $2514.20^{\mathrm{a}}$ & $2202.71^{\mathrm{a}}$ & $2519.92^{\mathrm{a}}$ & $2225.22^{\mathrm{a}}$ & $2151.22^{\mathrm{b}}$ & 23.22 & $*$ \\
\hline DWG, g per bird & $42.11^{\mathrm{a}}$ & $36.54^{\mathrm{b}}$ & $42.21^{\mathrm{a}}$ & $36.94^{\mathrm{b}}$ & $35.62^{c}$ & 0.38 & $*$ \\
\hline Total Feed Intake, g per bird & 3022.44 & 3048.48 & 3106.16 & 3040.66 & 2986.31 & 16.36 & NS \\
\hline Average daily feed intake & 53.97 & 54.43 & 55.46 & 54.29 & 52.43 & 0.54 & NS \\
\hline FCR & 1.28 & 1.48 & 1.31 & 1.46 & 1.47 & 0.04 & NS \\
\hline
\end{tabular}

Means within rows with different superscript letters are different $(\mathrm{P}<0.05)$. ${ }^{*} \mathrm{P}<0.05 ; \mathrm{NS}, \mathrm{P}>0.05$. SEM, standard error of mean. Data represent the mean value of 6 replicate pens of 10 birds.

Table 3 Carcass yield, relative weight (g/100 g body weight) of non-carcass parts, and internal organs of broilers fed graded levels of sun-dried Irish potatoes peel meal incorporated into diets

\begin{tabular}{|c|c|c|c|c|c|c|c|}
\hline Parameter & 0PPM & 25PPM & 50PPM & 75PPM & 100PPM & SEM & $\mathrm{P}$ \\
\hline Carcass weight (g) & $1791.3^{b}$ & $1983.2^{\mathrm{a}}$ & $1985.3^{a}$ & $1975.3^{\mathrm{a}}$ & $1995.9^{\mathrm{a}}$ & 7.09 & $*$ \\
\hline \multicolumn{8}{|l|}{ Relative weight of } \\
\hline Carcass & $79.6^{\mathrm{b}}$ & $83.3^{\mathrm{a}}$ & $88.0^{\mathrm{a}}$ & $86.9^{\mathrm{a}}$ & $87.0^{\mathrm{a}}$ & 2.18 & $*$ \\
\hline Breast & $17.80^{\mathrm{c}}$ & $19.40^{\mathrm{b}}$ & $21.30^{\mathrm{a}}$ & $20.10^{\mathrm{a}}$ & $22.60^{\mathrm{a}}$ & 2.00 & $*$ \\
\hline Thigh & $18.34^{\mathrm{c}}$ & $18.98^{\mathrm{c}}$ & $20.14^{\mathrm{ab}}$ & $25.11^{\mathrm{a}}$ & $25.35^{\mathrm{a}}$ & 1.08 & $*$ \\
\hline Wing & 9.30 & 9.24 & 9.44 & 9.32 & 9.82 & 1.11 & NS \\
\hline Back & 13.23 & 14.53 & 15.22 & 13.32 & 14.35 & 3.00 & NS \\
\hline Drumstick & $17.36^{\mathrm{b}}$ & $16.25^{\mathrm{c}}$ & $18.19^{\mathrm{ab}}$ & $17.02^{\mathrm{b}}$ & $24.35^{\mathrm{a}}$ & 2.98 & $*$ \\
\hline Lungs & $0.53^{\mathrm{b}}$ & $0.74^{\mathrm{a}}$ & $0.78^{\mathrm{a}}$ & $0.61^{\mathrm{a}}$ & $0.75^{\mathrm{a}}$ & 0.05 & $*$ \\
\hline Kidney & 0.76 & 0.78 & 0.79 & 0.72 & 0.76 & 0.90 & NS \\
\hline Heart & 0.52 & 0.52 & 0.55 & 0.50 & 0.54 & 0.08 & NS \\
\hline Gizzard & $1.74^{\mathrm{a}}$ & $1.43^{\mathrm{b}}$ & $1.43^{\mathrm{b}}$ & $1.56^{\mathrm{b}}$ & $1.42^{\mathrm{b}}$ & 1.00 & $*$ \\
\hline Liver & $1.86^{\mathrm{a}}$ & $1.89^{\mathrm{a}}$ & $1.13^{\mathrm{b}}$ & $1.29^{b}$ & $1.25^{\mathrm{b}}$ & $1.10^{\mathrm{b}}$ & $*$ \\
\hline
\end{tabular}

a,b: Means within rows with different superscript letters are different $(\mathrm{P}<0.05)$. ${ }^{*} \mathrm{P}<0.05$; NS, $\mathrm{P}>0.05$. SEM, standard error of mean. Data represent the mean value of 12 birds ( 6 replicate pens $\times 2$ birds per pen).

Table 4 Serum Biochemistry of broilers fed graded levels of sun-dried Irish potatoes peel meal incorporated into diets

\begin{tabular}{l|ccccccc}
\hline \multicolumn{1}{c|}{ Parameters } & 0PPM & 25PPM & $50 P P M$ & $75 P P M$ & $100 P P M$ & SEM & P \\
\hline Total protein (mmol/L) & $36.21^{\mathrm{b}}$ & $38.21^{\mathrm{ab}}$ & $40.23^{\mathrm{a}}$ & $44.76^{\mathrm{a}}$ & $46.21^{\mathrm{a}}$ & 0.41 & $*$ \\
Albumin(mmol/L) & $9.23^{\mathrm{b}}$ & $10.10^{\mathrm{a}}$ & $10.75^{\mathrm{a}}$ & $10.75^{\mathrm{a}}$ & $11.75^{\mathrm{a}}$ & 0.10 & $*$ \\
Globulin (mmol/L) & $27.72^{\mathrm{b}}$ & $30.21^{\mathrm{a}}$ & $33.25^{\mathrm{a}}$ & $34.30^{\mathrm{a}}$ & $28.21^{\mathrm{b}}$ & 0.31 & $*$ \\
Alkaline phosphates (i.u/l) & $13.13^{\mathrm{b}}$ & $15.72^{\mathrm{ab}}$ & $17.23^{\mathrm{a}}$ & $18.34^{\mathrm{a}}$ & $21.52^{\mathrm{a}}$ & 0.17 & $*$ \\
Creatinine (mmol/L) & $21.34^{\mathrm{a}}$ & $19.20^{\mathrm{a}}$ & $18.32^{\mathrm{ab}}$ & $16.76^{\mathrm{ab}}$ & $15.11^{\mathrm{c}}$ & 0.18 & $*$ \\
\hline
\end{tabular}

Means within rows with different superscript letters are different $(\mathrm{P}<0.05)$. ${ }^{*} \mathrm{P}<0.05$; NS, $\mathrm{P}>0.05$. Data represent the mean value of 12 birds $(6$ replicate pens $\times 2$ birds per pen). SEM, standard error of mean.

The dressing percent also followed the same trend as live weight however; broilers fed R3, R4 and R5 diets had comparable $(\mathrm{P}>0.05)$ thigh weight. Broilers fed $0.0 \%$ SPPM had significantly $(\mathrm{P}<0.05)$ smaller thigh and breast weights compared to birds on other treatment groups.

Lung weight of bird fed SPPM were significantly $(\mathrm{P}<0.05)$ heavier than those on control diet. Gizzard weight followed the same trend as lung weight. Higher value of gizzard weight was recorded by birds on control diet which was significantly $(\mathrm{P}<0.05)$ higher than birds fed SIPM - based diets

The result obtained for breast and thigh weights in this study is in line with the findings of (Okorie, 2010 and Okpanachi et al., 2015) who observed an increase in breast and thigh weight with an increase in inclusion level of cassava peel meal and brewers dried grains. Furthermore, the higher breast and thigh weight in this study with increasing levels of SIPM in diet may be an indication of better conversion of nutrients in the SIPM based-diet into meat.

Table 4 shows that Albumin level is lower in R1 diet with a value of 9.23 and highest in R5 diet with a value of 11.75. The value of alkaline phosphatase and total protein increased as the level of SIPM increased in the dietary treatments, ranging from 13.13 in R1 to 21.52 in R4 and to 36.21 to 46.21 respectively. Creatinine values however, decreased as the level of SIPM increased from 21.34 in R1 to 15.11 in R5. Diet 3 however had the highest globulin level of 34.33 while diet 1 had the lowest globulin level of 26.67. Despite the differences in albumin levels across the treatment groups, the values are within the ranges of $12.5 \mathrm{mmol} / 1$ to $22 \mathrm{mmol} / 1$ reported by (Akinmutimi and Onen, 2008). This is an indication that SIPM substitution did not adversely affect the nutritive quality of the experimental diets. 
Unlike all other parameters measured, birds on R1 recorded higher value (21.34) of Creatinine as the level of replacement increases. The finding in this study is similar to Okpanachi et al. 2015) who reported similar trend on birds fed Cassava tuber Meal, brewer's dried grain and palm Oil mixture.

According to Okpanachi et al. (2015) total proteins are the most abundant compound in serum. This is because they are involved in enzyme, hormones and antibodies synthesis. The values of total protein recorded in this study are within the normal physiological range of $32.5 \mathrm{mmol} / 1$ to $76.1 \mathrm{mmol} / 1$ reported by (Rajurker, 2009). This is an indication that the quality of protein in the experimental diet was adequate. Although globulin value differed among treatment groups, they were however within the normal range of $21.3 \mathrm{mmol} / 1$ to $30.2 \mathrm{mmol} / \mathrm{l}$ reported by (Adeyemo, 2008 and Okpanachi et al., 2015).

\section{Conclusion}

Proximate composition of SPPM contains moderate amounts of feed nutrients that can sustain broiler chickens for optimum performance. From the results of the feeding trial, it can be concluded that SPPM can substitute maize up to $75 \%$ in broiler chicken diets without any adverse effect on growth performance, carcass characteristics and serum biochemistry.

\section{Acknowledgement}

We wish to acknowledgment the management of Concordia College. Our appreciation goes to Mallam Tukur Isa and Ali Isa for their technical support

\section{References}

Abdo M, Mengistu U, Kefyalewa, G. 2015. Effects of replacing maize with sorghum on growth performance and feed efficiency of commercial broiler chicken. Journal of Verterinary Science and Technology, 6 (3).1-5

Adebayo AA, Tukur, AL.1999. Adamawa State in Maps. Paraclete Publishers. Yola. Pp 25

Adeyemo GO. 2008. Effects of cottonseed cake based diets on haematological and serum biochemistry of egg type chickens, International Journal of Poultry Science, 7(1), 23-27.
Afolayan M, Bawa GS, Sekoni AA, Abeke FO, Daramola ST. 2014. Effect of inclusion level of African Locust Bean (Parkia biglobosa) pulp on growth parameters of egg type chicken (020 weeks). Nigerian Journal of Animal Science, 16(1): 51-60

Akinmutimi AH, Onen GE. 2008. The response of broilers finisher birds fed graded levels of yam peel meal in place of maizebased diets. International Journal of Poultry Science, 7(5), 474479.

AOAC. 2000. Association of Analytical Chemist. Official Method of Analysis.131 ${ }^{\text {th }}$ Edition Washington D.C, USA. Pp1018

Bot MH, Bawa GS, Abeke FO.2013. Replacement value of maize with African locust bean (Parkia biglobosa) pulp meal on performance, haematological and carcass characteristics of broilers. Nigerian Journal of Animal Science, 15: 59-70.

Ekeyem BU, Madubuike FN, Dike OF. 2006. Effects of partial replacement of yam peel meal for maize on performance and carcass characteristics of finisher chickens. International Journal of Poultry Science, 5: 942-945.

Kleczek KE, Wilkiewicz-Wawro K, Makowski W. 2007. Effect of body weights of day-old Muscovy ducklings on growths and carcass traits. Arch. Tierz, 50(2), 204-213.

Midau A, Augustine C, Yakubu B, Yahaya SM, Kibon A, Udoyong AO. 2011. Effect of Enzyme supplemented cassava peel meal (CPM) on carcass characteristics of broiler chickens. International Journal of Sustainable Agriculture, 3(1): $21-24$

N.R.C. 1994. Nutrient Requirements of poultry, National Academy press, Washington D.C.

Okpanachi U, Musa AA, Adewoye AT, Adejoh OC. 2014. Effects of Replacing Maize with Graded Levels of Cassava Tuber Meal, Brewer's Dried Grain and Palm Oil Mixture on the Serum Biochemistry and Carcass Characteristics of Broiler Chickens. IOSR Journal of Agriculture and Veterinary Science 7, 27-31

Okorie KC, Gabriel O, Ehirim FN, Okorie RC, Ikpe JN, Muoneme CT, Okoro-Ugo C, Nwosu C. 2011. Effect of Synthetic Enzyme Fortified Brewers Dried Grain as Feed Source on Broilers Finisher; Performance, Haematology and Biochemical Profiles.Global Research Journal of Science, 1,123- 132

Olomu JM. 1995. Monogastric Animal Nutrition. Principles and Practice. A jacchem Publication PP 320

Oluyemi JA, Robert FA. 2000. Poultry production in warm-wet climate. Ibadan Nigeria: Spectrum Book Limited. $24-49$

Rajurker, J.I 2009. Total protein rangers ranges of animal, International Journal of Poultry Science 7(1) 23-27

Reitman S, Frankel S. 1957. A colorimetric method for the determination of serum glutamic oxaloacetic and glutamic pyruvic transaminases, American Journal of Clinical Pathology, 28; 56-63

Wafar RJ, Tarimbuka LI. 2016.Effects of quantitative Substitution of Maize with Sun-Dried Irish potatoes Peel Meal on Growth and Economic Performance of Weaner Rabbit. Proceedings 21 Annual Conference of Animal Science Association of Nigeria 18 - 22, 2016, Port Harcourt Pp. 845-849 